811.16'4-6

https://doi.org/10.18485/msc.2021.50.2.ch4

Сања Ј. ПАРИПОВИЋ КРЧМАР* Универзитет у Новом Саду Филозофски факултет
Оригинални научни рад

Примљен: 26. 10. 2020.

Прихваћен: 25. 2. 2021.

\title{
ЗАПАЖАЬА О КОМПАРАТИВНОЈ СЛОВЕНСКОЈ МЕТРИЦИ У СПИСИМА О СТИХУ И ПРЕПИСЦИ СВЕТОЗАРА ПЕТРОВИЋА*
}

\begin{abstract}
Увид у рукописну кореспонденцију академика Светозара Петровића са универзитетским професором у Висконсину Џејмсом Бејлијем, вођену током 2001. године, подстакао је изнова проблематизовање питања компаративне словенске метрике. Инострани колега, наиме, износи сумњу у валидност Јакобсонових идеја о лингвистичком објашњењу порекла словенског епског стиха, чиме покреће дискусију која преиспитује методолошке претпоставке и консеквенце Јакобсоновог приступа. Тако се кроз преписку увиђа процена С. Петровића о генетички оријентисаној компаративној метрици, која је у његовом раду о Јакобсоновом опису српскохрватског епског десетерца само наговештена. Дакле, овај рад интендира ново светло на критичку карактеризацију тог описа, те има за циљ да допуни реферат који је проф. Петровић на ту тему изложио 1974. године на ондашњем Научном састанку слависта у Вукове дане. Тако се конкретно реализује замисао осматрања пређеног пута из савремене теоријско-методолошке перспективе. Акценат ће бити усмерен на две тачке из преписке: спознаја лингвистичких фактора у историји стиха и примена закључака из историје лингвистике на историју версификације.

Кључне речи: Светозар Петровић, Џејмс Бејли, Иван Сламниг, Роман Јакобсон, компаративна словенска метрика, стих, језик.
\end{abstract}

\section{Увод}

На конференцији о компаративној словенској метрици одржаној у Варшави 1969. године Светозар Петровић је изложио део рада „Поредбено проучавање српскохрватскога епског десетерца и спорна питања његовог описа”, приказујући у уводном делу историјат дотадашњег поредбеног проучавања нашег стиха, а потом и питање „о методици елементарног описа која би се у

\footnotetext{
*sanja.paripovic@ff.uns.ac.rs

** Рад је настао у оквиру пројекта Аспекти идентитета и юихово обликовање у српској кьижевности (број 178005), који се уз финансијску подршку Министарства просвете и науке РС спроводи на Одсеку за српску књижевност Филозофског факултета у Новом Саду.
} 
случају епског десетерца морала примијенити како би се опис могао плодно искористити у сувременом поредбеном проучавању" (2003a: 165-166). Унутар тог прегледа проучавања представљена је подела на генетичка, права поредбена и поредбено-типолошка истраживања. У њему Петровић, између осталог, наговештава Јакобсонов [Рома́н О́сипович Якобсо́н] скептицизам према веровању о старини десетерачког размера, па и према самој идеји поредбених испитивања у словенској метрици, а засебан текст којим је предочена критичка карактеризација Јакобсоновог описа српскохрватског епског десетерца ${ }^{1}$ објављен је 1974. године као реферат на Научном састанку слависта у Вукове дане у Београдуㄹ․ Овај се Петровићев кратак оглед из историје филологије надовезује на претходни рад, али сада се не образлажу елементи описа епског десетерца, већ се испитују методолошке претпоставке и консеквенце тог описа, извори, садржај и природа Јакобсоновог поступка. Дакле, за предмет испитивања се узима сам текст аргументован чињеницом да Јакобсонов опис епског десетерца репрезентује далекосежни циљ великог научног интереса за проучавање овога размера, који се огледа у искушавању једне нове методологије у описивању стиха; чињеницом да је његов приказ фонолошког схватања стиха имао огроман одјек и утицао на даља проучавања у овој области. Међу пет одељака о специфичним особинама Јакобсоновог описа посебно издвајамо два: трећи одељак, који указује на хипотезу о индоевропском пореклу епског десетерца и идеју о генетички оријентисаној компаративној словенској метрици, у којој се подвлачи и да формулација те хипотезе није била у потпуности усклађена са општом лингвистичком концепцијом коју је Јакобсон заступао; и четврти одељак, са примедбом на Јакобсонов закључак о неодрживости поделе стихова по версификационим системима изведен из запажања о значају и ритмичких тенденција уз метричке константе; само разликовањем ових двеју метричких компоненти, прецизира Петровић, увиђамо хијерархију стиховних особина па на основу тога и разликујемо стихове квантитативне, силабичке и акценатске. Дакле, закључак о неодрживој подели није усклађен са сопственим узрочником, односно, није природно да из таквог запажања буде изведен такав закључак. Наиме, мишљења је Петровић, ово Јакобсоново исправно запажање о важности обе компоненте изведено је из неисправне претпоставке, веома утицајне на његова теоријска разматрања метрике, „да је стих одлучно, битно одређен језиком у коме је настао" (2003б: 224).

Поставке оба ова рада потребно је сагледати у светлу подлоге за кореспондентну размену мишљења академика Светозара Петровића са универзитетским професором у Висконсину Џејмсом Бејлијем [James Bailey], вођену током 2001. године, која реактуализује питање компаративне метрике, а које ћемо, уз навођење појединих сегмената, овде подразумевати. Инострани колега, наиме, износи сумњу у валидност Јакобсонових идеја о лингвистичком

\footnotetext{
${ }^{1}$ Јакобсон је овај опис изложио као реферат на међународном конгресу фонетичара у Амстердаму 1932.

${ }^{2}$ Овде се користимо верзијом рада штампаног поново у књизи Облик и смисао - Списи о стиху, 2003. године.
} 
објашњењу порекла словенског епског стиха, чиме покреће дискусију која преиспитује методологију Јакобсоновог приступа. Тако се кроз преписку увиђа процена С. Петровића о генетички оријентисаној компаративној метрици, која је у његовом раду о Јакобсоновом опису српскохрватског епског десетерца само наговештена. Постепено је расло интересовање за ово питање, од почетка марта 2001. када је било наговештено, све до пред крај октобра исте године када Петровић опсежно пише о овом проблему, уједно креирајући омаж колеги Ивану Сламнигу. Оживљавање успомена на преминулог колегу иницирало је подробније опсервирање о метрици, и оформило једно од релевантнијих мишљења проф. Петровића, које је подстицано кроз ову преписку са колегом Бејлијем.

\section{Разговор на тему компаративне словенске метрике ${ }^{3}$}

Светозар,

4. март $2001 .^{4}$

$[\ldots]$

И даље се надам да ћемо једном разговарати о компаративној словенској метрици. Јакобсон, Тарановски и остали су указали на ово питање, али сматрам да ми треба да преиспитамо тај приступ и истражимо и друге ствари. То се посебно тиче лирског стиха који је много разноврснији него епски стих.

Све најбоље,

Џејмс

19. март 2001.

Драги Џејмс,

$[\ldots]$

Компаративна словенска метрика? Нажалост, не знам радове о народном метру, у другим словенским језицима, који су урађени тако скрупулозно и тако методолошки као они које си ти урадио за Русе. Твоји резултати се само са великим опрезом могу упоредити са резултатима понуђеним било где. Тренутно, улога твоје књиге у другим словенским филологијама, по мом мишљењу, примарно би била да послужи као водич кроз пожељну процедуру. Потпуно си у праву да треба да преиспитамо приступ и Јакобсонов и других. Ти знаш моје примедбе на тај приступ. Мислим да у овом тренутку две тачке можемо сматрати најважнијим: изразита спознаја екстра лингвистичких фактора у историји стиха

\footnotetext{
${ }^{3}$ Издвајамо у писмима које смо превели са енглеског, само кључне сегменте о питању компаративне словенске метрике, изостављајући неке податке о личним животним ситуацијама, коментарима о књигама и радовима које су размењивали, подацима о издавачу и колегама који су учествовали у приређивању Бејлијеве књиге. Угласте заграде означавају део текста који смо изоставили; напомене приређивача такође су у угластим заградама. Сви коментари у фуснотама су наши. Сва писма која доносимо послата су електронском поштом; у рукописној оставштини налазе се одштампане верзије.

4 4. марта 2001. године Бејли узвраћа писмо Петровићу, који му је истог дана писао, те уз напомену о управо објављеној књизи радова на тему руског народног стиха, и уз информацију да је издавач обећао да ће примерак послати и Мирјани Стефановић и њему, наводи у последњем пасусу тог писма жељу за разговором на тему компаративне словенске метрике.
} 
и ризици разрешени у безбрижној дедукцији из историје лингвистике на историју версификације. ${ }^{5}$

Све најбоље,

Светозар

10. јул $2001 .{ }^{6}$

Драги Свето,

$[\ldots]$

Надам се да ћеш се вратити истраживању стиха. Допада ми се твоја идеја о могућој невалидности лингвистичког објашњења порекла словенског епског стиха. Пре извесног времена Курилович [Jerzy Kurylowicz] је сумњао у то. Моје сумње су расле и расле, али толико мало знам о осталим словенским језицима и не могу ништа рећи о грчком или санскриту, још мање о индоевропским језицима. Колико се сећам, Јакобсон је у почетку сумњао да је десетерац био древног порекла и полако је дошао до идеје да је настао од оригиналног десетосложног словенског епског стиха. Некако сумњам да је источнословенски икада имао такав стих. И шта је са бугарштицом која није била изосилабична? Надам се да ћеш ти бити у могућности да расветлиш ова питања.

$[\ldots]$

Желим ти све најбоље и добро лето.

Џејмс

13. август 2001.

Драги Свето,

$[\ldots]$

Волео бих да наставимо разговор о компаративној словенској метрици. Више нисам сигуран шта би то требало да значи, али и не знам довољно о словенским језицима да би ишта и рекао. Питам се да ли је источнословенски икада имао десетосложни епски стих. Несумњиво да ни у снимцима начињеним у последња два века ништа то не може да потврди.

Све најбоље,

Џејмс

21. октобар $2001 .^{7}$

Драги Џејмс,

$[\ldots]$

Размишљао сам о компаративној словенској метрици протеклих два месеца. То размишљање иницирао је тужан догађај. Било је неизбежно мислити о метрици док оживља-

\footnotetext{
${ }^{5}$ Овде се очито мисли на поменута два одељка из текста који преиспитује Јакобсонов приступ; процењујући да „развој стиха у историјско доба једноставно не потврђује претпоставку да су се смјене и промјене стиховних облика догађале на начин који би био успоредив са историјским развојем језика”, Петровић закључује да зато нема „никакве основе ни за наду да би било каква реконструкција изворних праоблика могла бити могућа у теорији стиха по прилици реконструкција у историјској лингвистици” (2003б: 222).

${ }^{6}$ Преписка се наставља 12. јуна; на дну одштампаног писма од тог датума стоји руком дописан податак: одг. 12. 6. / Моје писмо 15. 6. Следеће доступно писмо датирано 10. јула упућено је проф. Бејлију, али није сачувано писмо проф. Петровића од поменутог 15. 6. На основу садржаја писма да се и закључити да недостаје оно што је непосредно претходило. На дну тог писма руком је дописано: одг. 4. 8. Кратко писмо од 4. 8. 2001. године сачувано је у рукопису.

${ }^{7}$ Писмо које је претходило овом кључном опсервирању, датирано 20. октобра 2001, у виду је циркуларног писма о новим књигама из области фолклора које проф. Бејли упућује колеги Петровићу, сматрајући да би га то могло интересовати. У заглављу писма од 21. октобра стоји руком исписано: Comparative Slavic Metrics [i Slamnig]; 5 str. 45 kb; poslato 21. 10. 2001. У првом пасусу сазнајемо да је ово дуго писмо било написано почетком септембра, али је са слањем одлагано све до овог датума.
} 
вам успомене о веома блиском пријатељу који је преминуо пре два месеца, почетком јула. Његово име је Иван Сламниг.

$[\ldots]$

Посебна веза између Сламнига и мене била је метрика (поред нашег заједничког интересовања за ренесансну и барокну поезију). Тада се метрика није учила на загребачком универзитету (многи наши професори нису знали готово ништа о томе), тако да смо обојица били потпуно самоуки. Извори нашег интересовања били су различити: у Сламниговом случају, настало је на основу његових првих искустава у писању и превођењу поезије; у мом, углавном због незадовољства нашим књижевним курсевима којима су доминирале разноврсне мешавине културне и социјалне историје са испразним импресионизмом; комбиновано, наравно, са мојим читањем руских формалиста (доста њихових оригиналних публикација се могло наћи у загребачкој универзитетској библиотеци). Међутим, извори су мање важни од исхода; пред крај друге године студија, чини ми се, тај интерес је постао - и за Сламнига и за мене - доживотни избор привилегованог предмета промишљања и истраживања.

Сламниг је написао велики број радова о стиху, и знатно је указивао на метрику како у многим својим текстовима о појединим песницима тако и у есејима (и коментарима) о сопственим и туђим преводима. Књига Hrvatska versifikacija. Narav, povijest, veze (Zagreb $1981)$ бриљантно излаже његове идеје и једна је од најважнијих књига написаних о хрватском стиху (и, у ствари, о стиху у српско-хрватском језику уопште). Конципирана је као општи поглед на нарав стиха (његову природу, карактер) каква је установљена у значајним периодима његове повијести (историје) од средњег века до данас. По Сламниговом виђењу, везе (конекције, односи) са ширим интернационалним контекстом, којем је хрватска књижевност припадала током једног периода, одређивале су карактер стиха и његов репертоар унутар периода. Традиција је основа, подлога за калемљење (иијепна подлога) и истовремено одређује интернационалну књижевну заједницу која ствара наднационалне метричке оквире $\left(. .{ }^{8}\right)$, који се потом, унутар те заједнице, прилагођени поезији појединих језика, са адаптацијама у различитим језицима схватају као заједнички еквивалент. По Сламниговом мишљењу, услед лингвистичке сродности конституишу се такве наднационалне метричке јединице. На пример, у доба ренесансе, поезија на романским језицима (и на средњовековном латинском) била је повезана са поезијом на неколико словенских језика, па чак и са поезијом на мађарском језику, употребом заједничког сета метричких оквира (узгред, ови су се претпоставља се подједнако делили по мелодији и по речима песме).

У Сламниговом концепту постоји сегмент о компаративној словенској метрици по Јакобсоновом нацрту. Донекле је признао потенцијални значај лингвистичког сродства у метрици: на пример, одобравао је могућност да словенски језици развију симиларне адаптације међународних метричких оквира (што се може упоредити са Јакобсоновим очекивањем сличног одговора од сличног лингвистичког материјала на исте спољне формалне подражаје). Међутим, он је одбацио Јакобсонову реконструкцију прототипа компаративне словенске метрике, и у својим списима никада није детаљно образлагао ни једно од Јакобсонових појединачних реконструкција. Сламниг је веома добро познавао обе Јакобсонове главне студије објављење раних педесетих у $O C \Pi^{9}$ и $X C C^{10}$. Читали смо их мање више симултано премда независно један од другог, убрзо након њиховог објављивања, и пуно смо разговарали о тим радовима током педесетих и шездесетих година (најмање један од тих разговора памтим са сигурношћу, пре лета 1954. године када сам отишао у Индију на две године, пошто сам добио стипендију Индијске владе). Обојица смо били веома заин-

8 Петровић бележи маркиране речи у тексту на српско-хрватском језику латиницом (narav, povijest, veze, cijepna podloga, metrički okviri), а потом их у загради појашњава колеги синонимним речима у енглеском језику. Изостављамо појашњење у овој загради о употреби словне ознаке за ч у српско-хрватском језику.

${ }^{9}$ Oxford Slavonic Papers III, 1952, у којој је објављена студија „Studies in Comparative Slavic Metrics", на стр. 21-66.

${ }^{10}$ Harvard Slavic Studies I, 1953, 1-71, у којој је објављена студија „The Kernel of Comparative Slavic Literature", на стр. 23-34. 
тригирани читањем и сигуран сам да нам је обојици веома користило. Па ипак, били смо веома резервисани по питању Јакобсонових премиса и закључака.

Првобитно, били смо или узнемирени или забављени неким детаљима. На пример, Јакобсоновим навођењем моравског певача („седамдесетогодишње” жене, 1930. године) која је „дала деветом слогу стиха двоструку дужину од свих у поретку” (упркос чињеници да смо у тексту њене песме тешко уочили било какву фонолошку дужину на деветом слогу), и навођењем извођења деветог слога бугарског гуслара у Софији 1935. (који је певао на језику који као што се зна не познаје фонолошке опозиције дугих и кратких слогова) у доказивању старине и заједничког словенског порекла српско-хрватског епског десетерца; или пак, његовом причом о Матрјони Меншиковој ${ }^{11}$ која је, у својој старинској парафрази српске епике, преобликовала силабички десетерац „на исти начин као што је његов заједнички словенски прототип модификован руском усменом традицијом". ${ }^{12}$ Јакобсонов моравски певач Франт. Хесова и Матрјона Меншикова придружили су се групи надимака које смо Сламниг и ја користили неколико година у нашим шаљивим говорима, коришћеним углавном у брзим коментарима након читања нечијих радова или током слушања нечијег излагања на конференцији. [...]

Наравно да се наша резервисаност тицала много важнијих ствари од ових детаља. С почетка смо обојица сумњали, на пример, у веровање да се стиховни систем нужно изводио из прозодијског система појединачног језика, као и у веровање да је историја версификације датог језика нужно паралелна историји језика (да не кажем: предодређена том историјом). ${ }^{13}$ Па ипак, нисмо увек исказивали наше сумње под истим условима и свако их је смештао унутар сопственог ширег разумевања тог поља, тако да су наше процене Јакобсонове компаративне словенске метрике могле изгледати веће него што су заправо биле. Претпостављали смо, на пример, да су детаљи попут Франт. Хесове открили суштински недостатак Јакобсоновог настојања. Неуморно покушавајући да докаже поенту, Јакобсон је често спутавао свој осећај опреза; оно што је представио као најспектакуларнији резултат - његови ошптесловенски метрички прототипи - обојици се учинила као конструкција која је била превише чиста да би била истинита. Рекао бих: било је то објашњење без исправне верификације. Али бих додао: било је то изврсно објашњење образованог и талентованог човека, у виду „пророчког предвиђања уназад” (Шлегелова фраза коју је сам Јакобсон наводио са наклоношћу). И закључио бих: хеуристичка вредност Јакобсонове поставке је и даље неизмерна и већина његових сугестија заслужује пажљиву верификацију (што наравно подразумева и њихово евентуално оповргавање).

Претпостављам да се Сламниг не би изразито успротивио овим закључцима (вероватно би имао понеку ироничну опаску). Али сам их никада не би прихватио. Увек је инсистирао на раздвајању његове поезије од филолошког рада, и, вероватно зато што је био добар песник, никада није био милостив према 'поетским' упадима у ученост. Као научник, инсистирао је на 'чврстим чињеницама'. Одбацио је Јакобсонову компаративну словенску метрику, у суштини, као спекулативну поставку, која није доказана и која првобитно није ни доказива. Његово виђење питања историјског порекла стиховних облика приближно је закључку ignoramus et ignoramibus (узгред, чини се да је то било и Јакобсоново изворно виђење, током двадесетих година). Мислим да се много тога може рећи у корист тог става. Као прво, не чини се разборито претпоставити да су промене у версификацији, током векова у којима је доступни доказ оскудан индиректно или дословно непостојећи (научник се стога наводи да се одважи на њихову спекулативну реконструкцију), изведене на ра-

${ }^{11}$ У оригиналу стоји Matrjona Men'ssikova; у загради након имена Петровић објашњава - (ss kao sh, naravno).

12 Јакобсон је увидео да индоевропској версификацији потпуно одговара, по својим основним особинама-силабичност, квантитативна клаузула и цезура после 4. слога - српскохрватски епски десетерац, те је констатовао да је предак нашег стиха асиметрични тј. епски рецитативни стих општесловенски. Јужнословенски десетерац у виђењу појединих научника (нпр. Срезњевског) постаје тако изворни стих западнословенских стихова, а међу његовим потомцима Јакобсон је уврстио и стих руских билина (в. Петровић 2003a: 168-169).

13 Ова веровања нису утемељена у лингвистичким схватањима и не могу се доказати у оквирима лингвистичке теорије, наводио је Петровић у оквиру четвртог одељка критичког сагледавања Јакобсоновог описа стиха. 
дикално другачији начин у односу на промене у версификацији скорашњих векова. Чини се да бројни докази о последње наведеном указују на то да историја версификације дели са историјом поезије особину честе непредвидивости, тј. пуна је промена које се не могу објаснити позивањем ни на један стабилан фактор или на предвидив (ако већ не стабилан) скуп фактора. Чак и научник који је наклоњен традиционалном типу историјског детерминизма (и који би могао да цитира с одобравањем, као што је Јакобсон у више наврата чинио, изреку Жозефа де Местра [Joseph-Marie de Maistre] „Немојмо никад говорити о случају”) морао би да призна, испитавши доказе, да су промене у историји версификације, исто као и оне у историји поезије, догађаји настали као последица великог броја „узрока” (у комбинацијама које се разликују од једног догађаја од другог) и да би било мудро третирати их, у процесу њиховог изучавања, као случајне или јединствене догађаје, какво год да је научниково генерално опредељење у епистемологији.

Тврдећи да је Јакобсонова реконструкција била недоказива, Сламниг је тиме придао особит значај Јакобсоновом уверењу да се исти ефекат може произвести и постепеним развојем из заједничког извора и касним директним метричким утицајем на лингвистички сродан језик (случај Матрјоне Меншикове, итд.). Тврдио је да не можемо очекивати да се установи убедљив доказ било каквог заједничког порекла (мислим да је овај аргумент могао бити прихваћен са извесним квалификацијама; упореди фусноту 27 у мојој студији првобитно објављеној 1969. и поново штампаној у књизи Облик и смисао, на страни 210). ${ }^{14}$ Тако се Сламниг упустио у компаративно изучавање хрватске версификације у области наднационалних метричких оквира унутар одређених периода. Најважнији делови његове књиге били су они који су се тицали хрватске средњовековне и ренесансне поезије и српско-хрватске народне поезије истоветног периода. У оба случаја трагао је за проширењем метричких правила и обликовних модела ране романске популарне/усмене поезије (која је, мислио је, прелазила путању која се протезала од јужне Француске до северне Италије) и касне средњовековне латинске химнографије. Идеја романског и средњовековног латинског порекла српско-хрватских народних стихова сигурно није била нова (предложио ју је М. Г. Халански [Михаил Георгијевич Халански] деведесетих година 19. века, и претпостављала се у изучавању Н. Банашевића и других који су одржали значај романског утицаја на формирање српско-хрватског усменог епа), али је Сламниг био први који је то поткрепио прихватљивим метричким елаборатом. Сламниг је јасно препознао разлике по којима су романски и српско-хрватски силабизам два посебна типа стиха и спровео је комплексну анализу да би показао како важна промена у структури хрватског стиха у познијем средњем веку може бити изведена сличним променама у раној романској версификацији. Управо је у овом контексту настала брилијантна студија о најважнијем стиху у далматинској писаној поезији током ових векова: посебан тип дванаестерца (6+6), који је пркосио убедљивом опису у традиционалној српско-хрватској метрици (и стога обично није разликован од заједничког типа 6+6).

Сламнигова књига, у поређењу са оним што је представљено о српско-хрватској метрици у Јакобсоновом раду, показатељ је опсежнијег знања о сачуваним текстовима и веће свести о њиховој разноврсности (посебно у уважавању њиховог дијалекта и регионалне припадности). Сламниг је савесно описивао чињенице и утврђивао њихову повезаност. Међутим, таквим поступком, посебно када је примењен на народни метар, наишао је на озбиљне препреке. Занемарујући изузетно компликоване текстолошке проблеме који се тичу снимљених народних текстова пре пет векова, и чињенице да нису увек потпуно ја-

${ }^{14}$ У пасусу текста „Поредбено проучавање...”, који је маркиран поменутом фуснотом бр. 27, Петровић пише: „Било би такођер занимљиво огледати у међусобном односу оне хипотезе које у науци данас коегзистирају највише тако што се мимоилазе, али не би ваљало бити сигуран да ће њихов сусрет бити свакако плодан. Ако се питамо, наиме, о поријеклу једне појединачне појаве која се у разним сродним језицима налази модифицирана онолико колико се, према особитој структури појединог језика, предвидљиво морала модифицирати, лако је замислити тачку на којој ће опредјељење за једно од два могућа објашњења - за вертикалан развој из заједничког праоблика односно за хоризонтално ширење из неког трећег извора - бити углавном арбитрарно" (2003а: 174-175). У фусноти Петровић указује на неколико Сламнигових закључака о овом питању, сугеришући могуће смернице подробније анализе (в. 2003а: 210). 
сни, постојало је општије питање о репрезентативном моделу главног тока народне поезије тог периода. [...]

Уосталом, а што је и битније, чињеница није било много, о њиховој се природи још увек почесто полемише, и оне су изворно припадале различитим регионалним традицијама. Готово је било немогуће предложити било какво разумевање везе између тих чињеница без спекулативне реконструкције. С обзиром на неколицину чињеница (сива зона је била огромна), очекивало се да ће изграђивање кохерентног разумевања бити лако, а његова верификација веома тешка, готово немогућа. То значи да је вредност читавог пројекта зависила од научникове способности предвиђања, овога пута не уназад него у свим правцима. Без икакве жеље да то постане, испоставило се да је Сламниг био изврстан пророк у синхроности.

$[\ldots]$

Све најбоље теби и твојој супрузи,

Свето

$[\ldots]^{15}$

\section{Ка закључку}

Пред крај овога опсежног писма/елабората Петровић и сам резимира сва изнета разматрања овог питања речима: „Све ово, можда, води закључку да ни идеја о постојању статичне и хомогене наднационалне заједнице у одређеном времену, нити идеја о заједничком словенском наслеђу исправно преношена кроз многе векове, не одражавају потпуно (истински?) начин на који се стих мења, али да обе могу расветлити то питање уколико потичу од образованог и маштовитог човека. На основу чињенице да су се Јакобсон и Сламниг понекад могли заправо веома добро допуњавати, можемо износити тврдњу о корисности за њихове перспективе". Наиме, ово је један од главних разлога, по Петровићевом суду, тачније сусрет лингвисте са ученим истраживачем поезије, што специфичне особине Јакобсоновог описа српскохрватског епског десетерца нису постале „жртвом свим замкама које је његова усмјереност имплицирала" и што је ово значајно проучавање сачувало део своје вредности и до данас (2003б: 226).

\section{ЛИТЕРАТУРА}

Петровић 2003a: С. Петровић, Поредбено проучавање српскохрватског епског десетерца и спорна питања његовог описа, Облик и смисао - Cnuси о стиху, Београд: Фабрика књига, 165-216.

Петровић 2003б: С. Петровић, Јакобсонов опис српскохрватског епског десетерца, Облик и смисао - Списи о стиху, Београд: Фабрика књига, 217-227.

\footnotetext{
${ }^{15}$ Постскриптум у којем се објашњава разлог одлагања слања писма.
} 
Sanja J. Paripović Krčmar

\section{OBSERVATIONS ON COMPARATIVE SLAVIC METRICS IN WRITINGS ON A VERSE AND IN CORRESPONDENCE OF SVETOZAR PETROVIĆ}

\section{Summary}

In Svetozar Petrović's correspondence with the University of Wisconsin professor James Bailey, kept during 2001, the issues of comparative Slavic meter were again problematized. Doubts expressed about the validity of Jakobson's ideas on the linguistic explanation of the Slavic epic verse origin, initiated a discussion that re-examined the methodological assumptions and consequences of Jakobson's approach. Through the correspondence, one can see S. Petrović's assessment of genetically oriented comparative meter, which is only hinted at in his work on Jakobson's description of the Serbo-Croatian epic decasyllable. Reviving memories of colleague I. Slamnig initiated Petrović's detailed observation of the meter, which led to the conclusion of incorrect verification of Jakobson's explanation of Common Slavic metrical prototypes, and the conclusion that the idea of a common Slavic heritage correctly passed down through many centuries does not fully reflect the way the verse changes. 